Article

\title{
Assessment of Trace Metals in Sediments from Khnifiss Lagoon (Tarfaya, Morocco)
}

\author{
Ali Tnoumi ${ }^{1, *(\mathbb{D}, \text { Massimo Angelone }}{ }^{2}$, Giovanna Armiento ${ }^{2}$, Raffaela Caprioli ${ }^{2}$, Cinzia Crovato ${ }^{2}{ }^{(0)}$, \\ Maurizio De Cassan ${ }^{2}$, Maria Rita Montereali ${ }^{2}$, Elisa Nardi ${ }^{2,+}$, Luisa Parrella ${ }^{3}$, Marco Proposito ${ }^{2}$, \\ Fabio Spaziani ${ }^{2}$ (D) and Bendahhou Zourarah ${ }^{1}$
}

1 LGMSS-URAC45, Faculty of Sciences, Chouaib Doukkali University, El Jadida 24000, Morocco; zourarah.b@ucd.ac.ma

2 ENEA C.R. Casaccia, Department for Sustainability, 00123 Rome, Italy; massimo.angelone@enea.it (M.A.); giovanna.armiento@enea.it (G.A.); raffaela.caprioli@enea.it (R.C.); cinzia.crovato@enea.it (C.C.); maurizio.decassan@enea.it (M.D.C.); mariarita.montereali@enea.it (M.R.M.); elisa.nardi@isprambiente.it (E.N.); marco.proposito@enea.it (M.P.); fabio.spaziani@enea.it (F.S.)

3 ENEA C.R. Portici, Department for Sustainability, Portici, 00196 Naples, Italy; luisa.parrella@enea.it

* Correspondence: tnoumi.ali@gmail.com or tnoumi.a@ucd.ac.ma; Tel.: +212-664-649-183

+ Now working at ISPRA-The Italian National Institute for Environmental Protection and Research, 00144 Rome, Italy.

\begin{abstract}
Surface sediments from Khnifiss lagoon (Morocco) were analyzed to evaluate the contamination degree of the area. Concentrations of $\mathrm{V}, \mathrm{Cr}, \mathrm{Co}, \mathrm{Ni}, \mathrm{Cu}, \mathrm{Zn}, \mathrm{As}, \mathrm{Cd}, \mathrm{Hg}$, and $\mathrm{Pb}$ were determined on samples taken during the summer and the autumn of 2016. On the whole, higher concentrations were found in the summer season. The results revealed the following average concentrations $(\mathrm{mg} / \mathrm{kg})$, reported in descending order: $\mathrm{Zn}(51.7 \pm 31.3)>\mathrm{V}(38.8 \pm 24.7)>\mathrm{Cr}(26.6 \pm$ $17.8)>\mathrm{Ni}(16.5 \pm 5.47)>\mathrm{As}(8.50 \pm 2.00)>\mathrm{Cu}(6.60 \pm 3.81)>\mathrm{Pb}(6.13 \pm 3.46)>\mathrm{Co}(3.57 \pm 2.09)$ $>\mathrm{Cd}(0.16 \pm 0.11)>\mathrm{Hg}(0.006 \pm 0.001)$. Organic matter showed a positive significant correlation with some trace metals (mainly $\mathrm{V}, \mathrm{Cr}, \mathrm{Co}, \mathrm{Zn}, \mathrm{Cd}, \mathrm{Pb}$ ). Three pollution indices were calculated: Enrichment Factor (EF), Index of Geo-accumulation (Igeo), and Pollution Load Index (PLI). Minimal enrichments (for Zn, As, and Cd) were detected at some sampling points. Overall indices showed that the Khnifiss sediments can be classified as not contaminated, and that the trace metals amounts found are ascribable to the geogenic origin. The results of this work can be used as a starting point for further evaluations of trace metals distribution in Moroccan lagoons.
\end{abstract}

Keywords: Khnifiss Lagoon; trace metals; enrichment factor; sediment geochemistry; contamination assessment

Received: 19 November 2020

Accepted: 7 December 2020

Published: 23 December 2020

Publisher's Note: MDPI stays neutral with regard to jurisdictional claims in published maps and institutional affiliations.

Copyright: () 2020 by the authors. Licensee MDPI, Basel, Switzerland. This article is an open access article distributed under the terms and conditions of the Creative Commons Attribution (CC BY) license (https: / / creativecommons.org/ licenses/by/4.0/).

\section{Introduction}

Coastal lagoons are very important environments, both in ecological and in economic terms, since they provide the habitat for numerous species and are the backbone of various anthropic activities (including food-related ones and tourism) [1,2]. However, the human exploitation of these ecosystems implies a significant potential environmental vulnerability, especially due to their geo-morphological setting (as semi-enclosed area) and their link to terrestrial inputs and continental run-off [3,4]. Indeed, the presence of trace metals in lagoons and coastal zones has been attributed mutually to natural events (volcanism, flash flood, wind transport, erosion) and anthropogenic processes (vehicle emission, industry, urbanization, construction activities, mining activities) [5-8]; for these reasons, lagoon sediments can act both as geogenic source and as a final sink for trace metals in the aquatic ecosystems $[9,10]$. They can be considered as good geo-indicators of marine environmental quality, since their status can alter benthos and the food chain, thus posing potential ecological risks $[11,12]$. Therefore, the study of coastal sediments provides useful information on marine pollution [13]. Trace metals are persistent in the environment and 
are subject to bioaccumulation (which often causes irreversible adverse effects on animals and humans) $[14,15]$. In addition, they represent a global-scale environmental issue, since serious problems caused by this category of pollutants are known to exist in many areas of the world (both in developed and developing countries) [16,17]. More than $90 \%$ of trace metals load in aquatic systems is associated with suspended particulate matter and sediments $[18,19]$. The fate and transport of these elements in marine area and lagoons are controlled by a variety of factors such as redox potential, texture, ionic strength, the abundance of adsorbing surfaces, $\mathrm{pH}$, and organic matter content $[20,21]$. The environmental monitoring helps to develop effective management plans, to improve the strategies for coastal activities, and to distinguish between the anthropogenic and the natural sources of the trace metal enrichments.

Morocco acts as an especially relevant site for the study of coastal ecosystems, since it holds five lagoons: Four facing the Atlantic Ocean (Khnifiss, Sidi Moussa, Oualidia, and Moulay Bousselham lagoons) and one facing the Mediterranean Sea (Marchica Lagoon), covering about $3500 \mathrm{Km}$ of the national coastline. The present study focuses on the most important desert wetland in the Saharan coast of Morocco and of North Africa (RAMSAR site since 1980): The lagoon of Khnifiss. It is a shallow tidal lagoon of open water in an arid environment, where the supply of continental material is strongly limited to aeolian particle inputs; in addition, a coastal upwelling from the Canary Islands induces high biogenic accumulation rates [22]. Although Khnifiss Lagoon is currently protected, information on its sediment's metal concentrations is still lacking. The relevance of Khnifiss Lagoon is further strengthened considering that there is a proposal to use the area as a reference site for the evaluation of trace metal contamination levels, since it is characterized by abundant and various macrobenthic fauna [23], low density of human population (1.07 per $/ \mathrm{km}^{2}$ at Tarfaya Province) [24], and it is far from major cities and industrial activities.

The main objectives of this research are to determine the trace metal contents in the Khnifiss Lagoon, in order to assess the contamination degree of the area; to carry out a preliminary screening that can be used as starting-point for a more detailed activity of geochemical study.

\section{Materials and Methods}

\subsection{Geo-Environmental Setting of the Area}

The study area is located in the Province of Tarfaya, between Cap Nachtigal and Cap Juby, in a rural region on the Southwest side of Morocco $\left(27.80-28.05^{\circ} \mathrm{N}, 12.21-12.39^{\circ} \mathrm{W}\right)$. It extends for about $20 \mathrm{~km}$, with a maximum of about $5 \mathrm{~km}$ width, at Sabkha Tazera [25]. The site is considered one of the most important zones for birds' migrations. Besides, it provides the livelihood of people living in adjacent areas, where most activities are related to fishing and nature tourism.

The lagoon is connected to the Atlantic Ocean through Foum Agoutir at its Northern side. The tidal regime is semidiurnal, and it ranges between a minimum of $1.48 \mathrm{~m}$ downstream to a maximum of $2.54 \mathrm{~m}$ inside the lagoon. The speed of the tidal current exceeds $91 \mathrm{~cm} / \mathrm{s}$ at Foum Agoutir. The residence time of the water in the lagoon is 4.4 tidal cycles during neap tides and 1.5 tidal cycles during spring tides [26]. Salinity is between $30 \%$ and $40 \%$ in the downstream zone, between $32 \%$ and $45 \%$ in the intermediate zone, and between $37 \%$ and over $45 \%$ in the upstream zone due to the saltworks at Sebkha Tazera [27]. The phytoplankton community is dominated by diatoms $(90 \%)$ and dinoflagellates $(10 \%)$, with Chaetoceros $(88.5 \%)$ and Amphora $(6.7 \%)$ being the main exponents of the population [28]. The lagoon has varieties of floral species such as Zygophyllum geatulum, Launaea arborescens, Lycium intricatum, Cistanche phelypaea, Zostera noltii, and Spartina maritima [29]; seaweeds are mainly represented by 24 species (4 Chlorophyceae, 10 Phaeophyceae, and 10 Rhodophyceae) [30]. The air temperature ranges between a minimum of $15.8 \pm 2.5^{\circ} \mathrm{C}$ to a maximum of $24.0 \pm 2.2^{\circ} \mathrm{C}$ with an average of $19.9 \pm 2.2^{\circ} \mathrm{C}$. The precipitations are classified as extremely rare, with an average of $0.3 \pm 0.2 \mathrm{~mm}$ daily and $92.6 \pm 58.5 \mathrm{~mm}$ annually 
over the last three decades (1994-2019). The wind speed ranges between $4.47 \pm 0.53 \mathrm{~m} / \mathrm{s}$ to $7.90 \pm 0.82 \mathrm{~m} / \mathrm{s}$, with an average of $6.13 \pm 0.41 \mathrm{~m} / \mathrm{s}$.

The geomorphology of the region is conditioned by the presence of Cretaceous marl or marly-limestone, to which it is over-imposed a harder calcareous-sandstone (Marine Moghrebien) protective slab. From a geological point of view (Figure 1), the study area is located in the North-Eastern side of Tarfaya coastal basin, formed during the Mesozoic and the Cenozoic seaward of the stable West African craton [31]. The main sources of the sediments are the Anti-Atlas in the Est, and the Reguibat dorsal and Mauritanides in the Southern part [32,33].

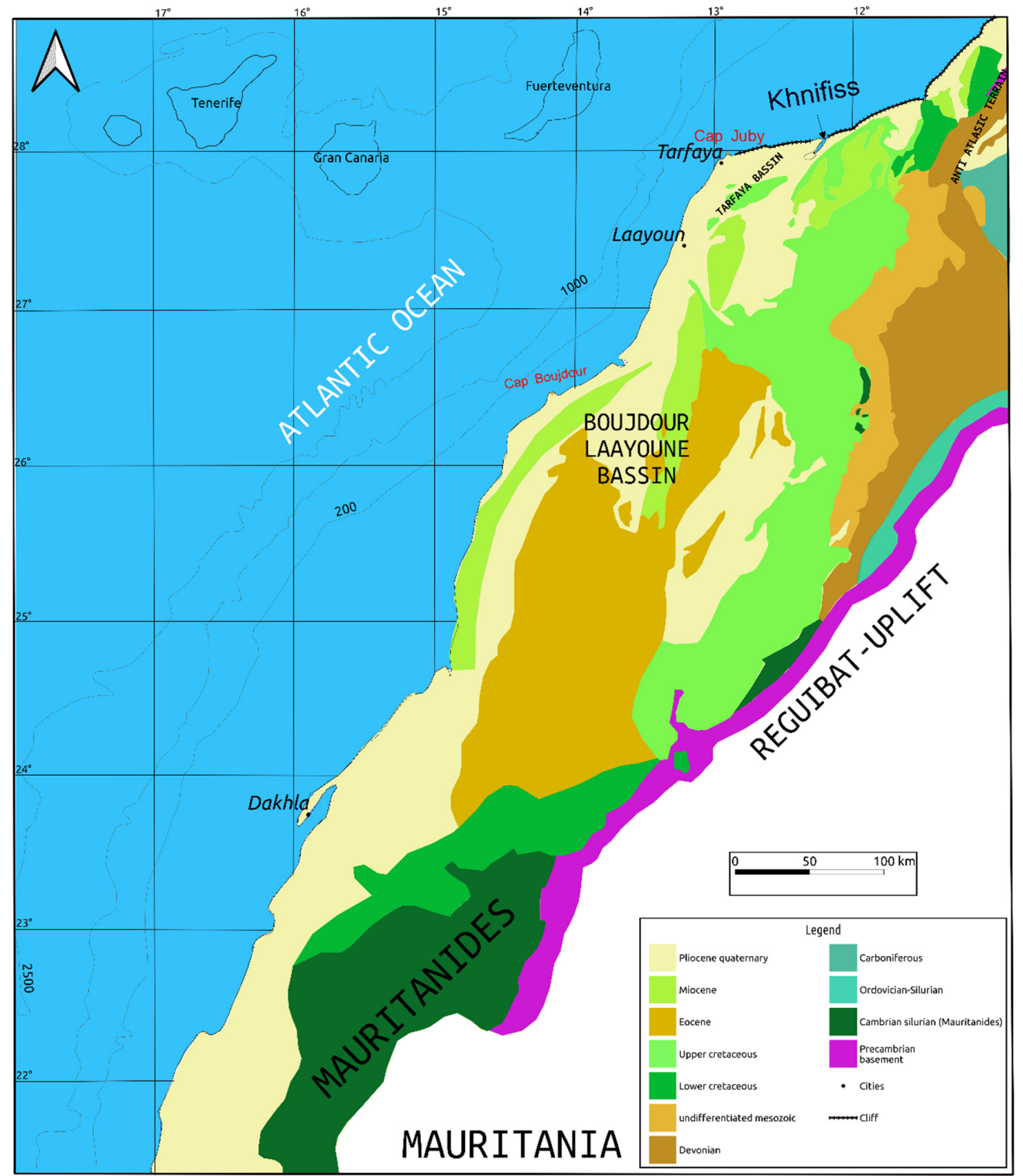

Figure 1. Geological map of the area surrounding the Khnifiss Lagoon (Digitalized from [34]).

\subsection{Sediment Sampling and Analysis}

Surface sediments were collected in 2016, during two seasons (summer and autumn), at six different stations (S1-S6), for a total of 12 samples, ensuring spatial coverage of the lagoon (Figure 2). The sediments were taken using a stainless steel Van Veen grab sampler, between $0-5 \mathrm{~cm}$ depth. The tools were washed with lagoon water before sampling. The sediments were stored in airtight polyethylene bags, labeled, and immediately frozen at $-20{ }^{\circ} \mathrm{C}$ until further processing. The location of each sample was recorded by a GPS. 
At the laboratory, the sediments were defrosted by keeping them at room temperature for about $24 \mathrm{~h}$, then dried in an oven at $40^{\circ} \mathrm{C}$ (it has been proved by Gilli et al. [35] that samples drying at $40^{\circ} \mathrm{C}$ does not cause evaporation losses of $\mathrm{Hg}$ ). The samples were at last crushed using a mortar grinder, homogenized, stored inside polyethylene bags until the chemical analyses were carried out.

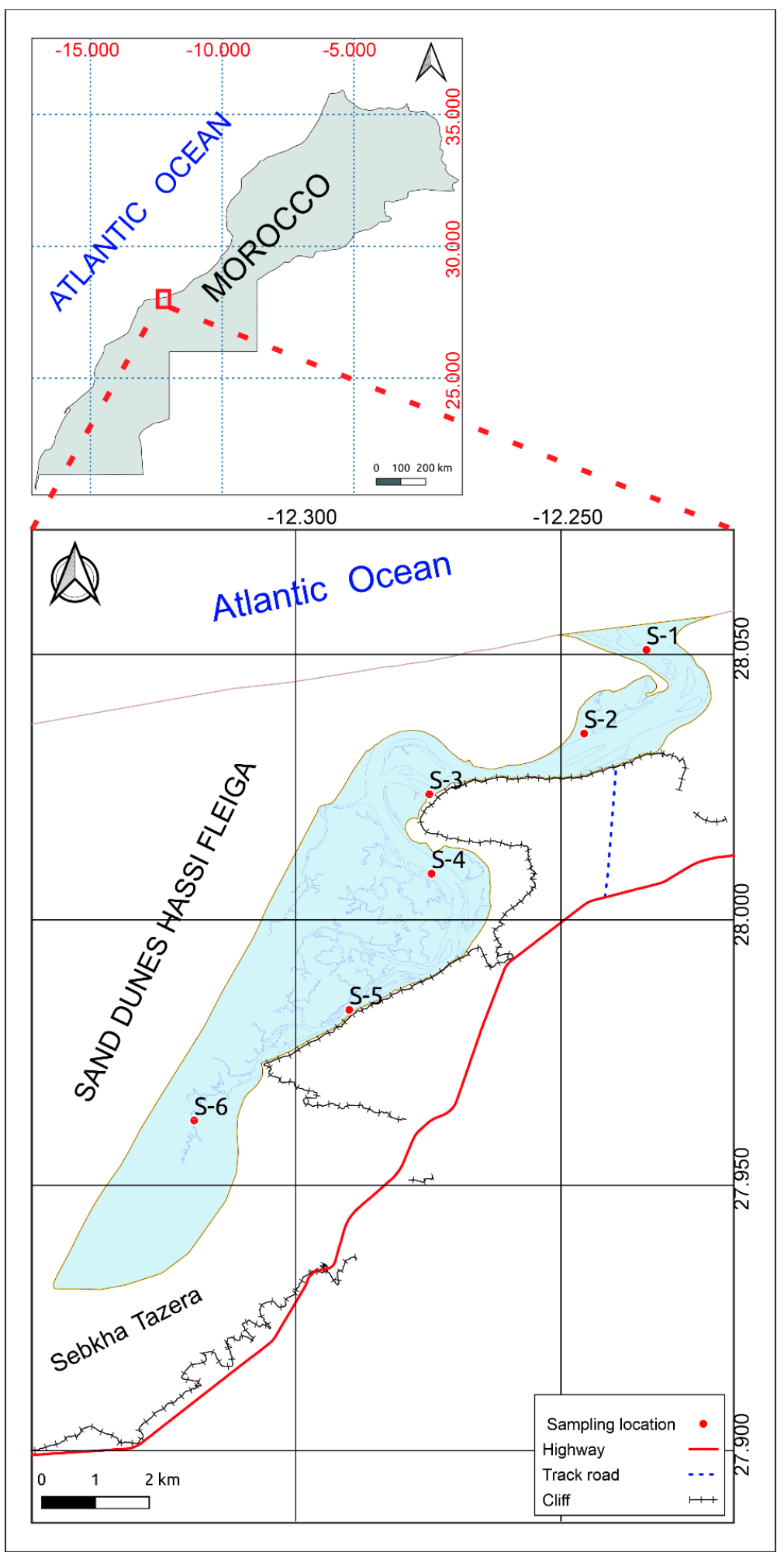

Figure 2. Map of the sampling locations at Khnifiss Lagoon. 
The determinations of trace metals (except $\mathrm{Hg}$ ) were accomplished using a microwaveassisted acid dissolution procedure, according to EPA method 3052, followed by the chemical analyses performed by: (i) An ICP-MS instrument (Perkin Elmer ELAN 6100) for the quantification of $\mathrm{V}, \mathrm{Cr}, \mathrm{Co}, \mathrm{Ni}, \mathrm{Cu}, \mathrm{Zn}, \mathrm{As}, \mathrm{Cd}$, and $\mathrm{Pb}$ (according to EPA method 6020 b); (ii) an ICP-OES instrument (Perkin Elmer Optima-2000 DV) for Al (according to EPA method $6010 \mathrm{~d}$ ). All the reagents were of analytical grade. The analysis of $\mathrm{Hg}$ was carried out by the automated mercury analyzer FKV AMA-254; the advantage of this device is that $\mathrm{Hg}$ is directly determined on the dry sample and the acid dissolution step is not required [36]. Precision and accuracy were verified using marine sediment reference certified materials (PACS-3 and MESS-4; National Research Council Canada, NRCC): The recoveries of $\mathrm{Al}, \mathrm{V}, \mathrm{Cr}, \mathrm{Co}, \mathrm{Ni}, \mathrm{Cu}, \mathrm{Zn}, \mathrm{As}, \mathrm{Cd}, \mathrm{Hg}$, and $\mathrm{Pb}$ in MESS -4 ranged from 84.0 to $118.5 \%$; the recoveries of $\mathrm{Al}, \mathrm{V}, \mathrm{Cr}, \mathrm{Co}, \mathrm{Ni}, \mathrm{Cu}, \mathrm{Zn}, \mathrm{As}, \mathrm{Cd}$, and $\mathrm{Pb}$ in PACS -3 ranged from 88.1 to $100.5 \%$. For all the elements, the quantitation limits were: $\mathrm{V}, \mathrm{Co}, \mathrm{As}$, $\mathrm{Pb}=0.05 \mathrm{mg} / \mathrm{kg} ; \mathrm{Cd}=0.03 \mathrm{mg} / \mathrm{kg} ; \mathrm{Cr}=0.5 \mathrm{mg} / \mathrm{kg} ; \mathrm{Ni}, \mathrm{Cu}=0.3 \mathrm{mg} / \mathrm{kg} ; \mathrm{Zn}=1.0 \mathrm{mg} / \mathrm{kg}$; $\mathrm{Hg}=0.005 \mathrm{mg} / \mathrm{kg} ; \mathrm{Al}=50 \mathrm{mg} / \mathrm{kg}$.

Organic matter $(\mathrm{OM})$, which in sea sediments originates from marine and terrestrial sources, was determined by Loss-On-Ignition procedure (LOI) [37]. About $4 \mathrm{~g}$ of each sediment were weighed and transferred in a porcelain crucible. The samples were heated at $105^{\circ} \mathrm{C}$ for $24 \mathrm{~h}$ to remove the moisture content and the new weight was determined; then, the samples were kept in a muffle furnace at $550{ }^{\circ} \mathrm{C}$ for $4 \mathrm{~h}$ and weighed again. Lastly, the organic matter was calculated according to Equation (1):

$$
\text { LOI }=\frac{\left(\text { Weight }_{105{ }^{\circ} \mathrm{C}}-\text { Weight }_{550}{ }^{\circ} \mathrm{C}\right)}{\left(\text { Weight }_{105}{ }^{\circ} \mathrm{C}\right)} \times 100
$$

The calcium carbonate content $\left(\mathrm{CaCO}_{3}\right)$ was measured by volumetric calcimetry, using a Bernard calcimeter [38,39]. Grain size measurement was determined using both dry and wet separation techniques [40-42]: The samples were pre-treated with $\mathrm{H}_{2} \mathrm{O}_{2}$ and washed with bi-distilled water to remove organic matter and chlorides, then oven-dried at $40{ }^{\circ} \mathrm{C}$ for $24 \mathrm{~h}$; the coarse fraction was isolated by sieving, while the fine fraction $(<63 \mu \mathrm{m})$ was ultrasonically dispersed using $0.5 \sim 10 \%$ sodium hexametaphosphate $\left(\mathrm{NaPO}_{3}\right)_{6}$ for $24 \mathrm{~h}$ and analyzed by a particle size analyzer (Micromeritics, SediGraph).

\subsection{Pollution Indices}

To assess the levels of trace metal contamination and the possible anthropogenic impact on the sediments, three of the most used pollution indices were applied [43,44]: Enrichment Factor (EF), Index of geo-accumulation (Igeo), and Pollution Load Index (PLI). The calculations of the indices require the use of reference values from a background matrix, and the Shale data proposed by Turekian and Wedepohl [45] were chosen for this study (because local geochemical background values were not available).

The EF is used to evaluate the degree of anthropogenic influence on the occurrence of a metal in the soil/sediment; it is calculated through the ratio of the metal concentration in the sample with respect to the background matrix, using a normalizing element [46]. Several conservative elements have been used for normalization purposes [47-49], but we selected $\mathrm{Al}$ since it is generally the major constituent of clay minerals.

The EF for a trace metal is expressed as follow (Equation (2)):

$$
\mathrm{EF}=\frac{\left(C_{n} / C_{A l}\right) \text { Sample }}{\left(C_{n} / C_{A l}\right) \text { Background }}
$$

where $C_{n}$ and $C_{A l}$ are the concentrations of the trace metal $(n)$ and $\mathrm{Al}$. 
The Igeo index, originally developed by Muller [50], was used to quantify the metal contamination related both to natural events and/or human activities [51]. It is calculated according to Equation (3):

$$
\text { Igeo }=\log _{2}\left(\frac{C_{n}}{k \times B_{n}}\right)
$$

where $C_{n}$ is the concentration of the metal $(n)$ in the sample and $B_{n}$ is the geochemical background value of the same element [52]. The constant $k=1.5$ is used as a correction coefficient for natural fluctuations in background values as well as for very small anthropogenic influences [50].

PLI provides an integrated and site wise comparative assessment of cumulative trace metal pollution [53]. This index can be interpreted as an appraisal of the comprehensive trace metal pollution in a given sample. It is calculated using the Equations (4) and (5):

$$
\begin{gathered}
\text { PLI }=\sqrt[n]{\left(\mathrm{CF}_{1}\right) \times\left(\mathrm{CF}_{2}\right) \times\left(\mathrm{CF}_{3}\right) \times \ldots \times\left(\mathrm{CF}_{n}\right)} \\
\mathrm{CF}=\mathrm{C}_{\text {Sample }} / \mathrm{C}_{\text {Background }}
\end{gathered}
$$

where $\mathrm{CF}$ is the contamination factor, $\mathrm{C}_{\text {Sample }}$ is the concentration of a selected metal in the sample, and $\mathrm{C}_{\mathrm{Background}}$ is the amount of the same element in the background matrix. Each index evaluates the sample quality according to the scores and classes [53-55] reported

\begin{tabular}{|c|c|c|c|c|c|}
\hline PLI [53] & Degree of Contamination & Igeo [54] & Degree of Contamination & EF [55] & Degree of Contamination \\
\hline$<1$ & Unpolluted & Igeo $\leq 0$ & Uncontaminated & $\mathrm{EF}<2$ & No enrichment/Depletion to mineral \\
\hline \multirow[t]{6}{*}{$>1$} & Polluted & $0<$ Igeo $\leq 1$ & Uncontaminated to moderately & $2 \leq \mathrm{EF}<5$ & Moderate enrichment \\
\hline & & $1<$ Igeo $\leq 2$ & Moderately contaminated & $5 \leq \mathrm{EF}<20$ & Significant enrichment \\
\hline & & $2<$ Igeo $\leq 3$ & Moderately to highly contaminated & $20 \leq \mathrm{EF}<40$ & Very high enrichment \\
\hline & & $3<$ Igeo $\leq 4$ & Highly contaminated & $\overline{\mathrm{EF}} \geq 40$ & Extremely enrichment \\
\hline & & $4<$ Igeo $\leq 5$ & Highly to extremely contaminated & & \\
\hline & & Igeo $>5$ & Extremely contaminated & & \\
\hline
\end{tabular}
in Table 1.

Table 1. Scores and classes of Pollution Load index (PLI), Index of geo-accumulation (Igeo), and Enrichment Factor (EF).

\subsection{Correlation Analysis}

The data processing was performed using $\mathrm{R}$ statistical software [56]. Mean, maximum, minimum, standard deviation, first quartile, third quartile, and Skewness were calculated. The Shapiro-Wilk test was used to assess the normality of the dataset. Since the data were not normally distributed, the Spearman correlation coefficient was used in order to identify any significant pattern and relationship between the variables.

\section{Results and Discussion}

\subsection{Geochemical Results}

The complete dataset and the descriptive statistics are summarized in Table 2. The sediments of the lagoon showed a moderately alkaline $\mathrm{pH}$, which ranged from 7.55 to 8.27, and exhibited spatial differences in the occurrence of trace metals (Figure 3). Stations S-2, S-4, and S-6 revealed higher concentrations compared to other locations, probably due to different grain size distribution; these samples, indeed, may have a larger accumulation of fine grained terrigenous and marine materials as reflected by their higher amounts of $\mathrm{Al}$. In the summer season, station S-4 stands out for the higher concentrations exhibited for all the elements. In autumn, instead, $\mathrm{S}-6$ has higher concentrations of $\mathrm{V}, \mathrm{Cr}, \mathrm{Co}, \mathrm{Cu}, \mathrm{Zn}, \mathrm{As}$, $\mathrm{Hg}$, and $\mathrm{Pb}$, while S-2 and S-4 had the maximum amounts of $\mathrm{Ni}$ and $\mathrm{Cd}$.

The OM in sediments is a key parameter since it is related to the ability to concentrate (either by ion exchange and/or complexation) and release metals in marine and lagoon waters, and it is also a source of nutrients for aquatic fauna [57]. It ranged between 1.50 and $7.56 \%$, with an average of $3.78 \%$ (Figure 4 ). The lowest amounts were observed, in both seasons, at S-1 (Foum Agoutir, inlet of the lagoon), due to high hydrodynamic characteristic 
at this station and for the prevalence of sandy texture [26]. Generally, sediments in rough waters are sandy and then exhibit lower metal contents [47]. On the contrary, the maximum amounts of OM, that speed up the adsorption of the metals from the overlying water to bottom sediments, were recorded at station S-2 and S-4 due to the presence of seagrass, which encourages the retention of the fine particles. The relatively higher concentrations observed during the summer season for most of the trace metals may be attributed to the small differences in OM contents, having an average of $3.92 \pm 2.63 \%$ compared to the $3.65 \pm 2.28 \%$ in autumn. The lower OM in fall may be a consequence of elevated decomposition rates fostered by high levels of dissolved oxygen [27]. However, the lower metal concentrations found during the autumn might be also related to their mobilization from the sediments promoted by the overlying water. The ranges of OM percentages were compared to other Moroccan Lagoons, e.g., Moulay Bousselham Lagoon (1.24-15.74\%) [58] and Oualidia lagoon (7.56-15.23\%) [59]. The comparison showed that the OM values in the Khnifiss Lagoon sediments are about two times lower than the ones from the other local lagoons. This could justify the low concentration values of trace metals measured in this lagoon. Lefrere et al. [23] achieved the same conclusion using benthic fauna. In addition, the lagoon receives neither freshwater supply from the mainland nor waste discharges, and therefore is characterized only by a continuous renewal of water according to the current tidal trend [26].

The carbonate concentrations varied in a range of $8.25-58.8 \%$ and the highest values were registered, in both seasons, in stations $\mathrm{S}-1$ and $\mathrm{S}-3$. These results are reasonably related to the nature of the sediments since the presence of limestone fragments (from shells and snails) causes the rise of carbonate contents. The importance of determining and studying carbonates in marine systems is related to their ability to adsorb metal forming labile species [60].

Overall, the means of the analyzed elements are below the average shale's values $[45,61,62]$ (Table 2) indicating low metal concentrations in the lagoon sediments (Figure 2). The world average shale value represents the background concentration of metals in a collection of several sedimentary rocks derived from argillaceous materials worldwide.

\subsection{Contamination Degree Assessment}

Pollution indices may help to quantify the level of enrichment of a sediment with trace metals [63]. The EFs calculated on the dataset are reported in Table 3. All the stations showed no enrichments $(\mathrm{EF}<2)$ for $\mathrm{V}, \mathrm{Cr}, \mathrm{Co}, \mathrm{Ni}, \mathrm{Cu}, \mathrm{Hg}$, and $\mathrm{Pb}$, both concerning the summer and the autumn, thus indicating concentration levels close to the natural background for marine sediments [55]. Moderate enrichments $(2 \leq \mathrm{EF}<5)$ were found: For Cd (sample S-4) and Zn (sample S-6) in summer, that can be linked to the upwelling phenomenon of cold water masses on the southern Atlantic coasts of Morocco. Our findings corroborate with results of Idardare et al. [64] using Nereis diversicolor as bio-indicator; for As in both the seasons ( $\mathrm{S}-1, \mathrm{~S}-3, \mathrm{~S}-5$ in summer and $\mathrm{S}-1, \mathrm{~S}-3, \mathrm{~S}-5, \mathrm{~S}-6$ in autumn), that can be attributed to the lithology of this area and especially to the presence of schist rocks $[64,65]$. On the whole, EF index values showed the following trend in summer As $>$ $\mathrm{Zn}>\mathrm{Cd}>\mathrm{Pb}>\mathrm{V}>\mathrm{Cr}>\mathrm{Ni}>\mathrm{Co}>\mathrm{Cu}>\mathrm{Hg}$ and the following one in autumn As $>\mathrm{Cd}>\mathrm{Zn}$ $>\mathrm{Pb}>\mathrm{V}>\mathrm{Cr}>\mathrm{Ni}>\mathrm{Co}>\mathrm{Cu}>\mathrm{Hg}$. Nevertheless, according to Atgin et al. [66], EF values less than 5 cannot be considered noteworthy, and a minor enrichment can be related to the effect of the lithology. The Igeo results are summarized in Figure 5, showing that all the sampling stations can be classified as "uncontaminated" for the studied trace metals $($ Igeo $<0)$. The PLI values for all the samples ranged from 0.07 to 0.43 , with averages of 0.22 and 0.20 in summer and autumn, respectively. The PLI trends were as follow: $\mathrm{S}-4>$ $\mathrm{S}-2>\mathrm{S}-6>\mathrm{S}-5>\mathrm{S}-3>\mathrm{S}-1$ in summer, and $\mathrm{S}-6>\mathrm{S}-2>\mathrm{S}-4>\mathrm{S}-5>\mathrm{S}-3>\mathrm{S}-1$ in autumn (Figure 6). This index supports again the evidence that no appreciable input from anthropogenic sources affects the area $(\mathrm{PLI}<1)$. 
Table 2. Geochemical analysis results and descriptive statistics in surface sediments from Khnifiss Lagoon.

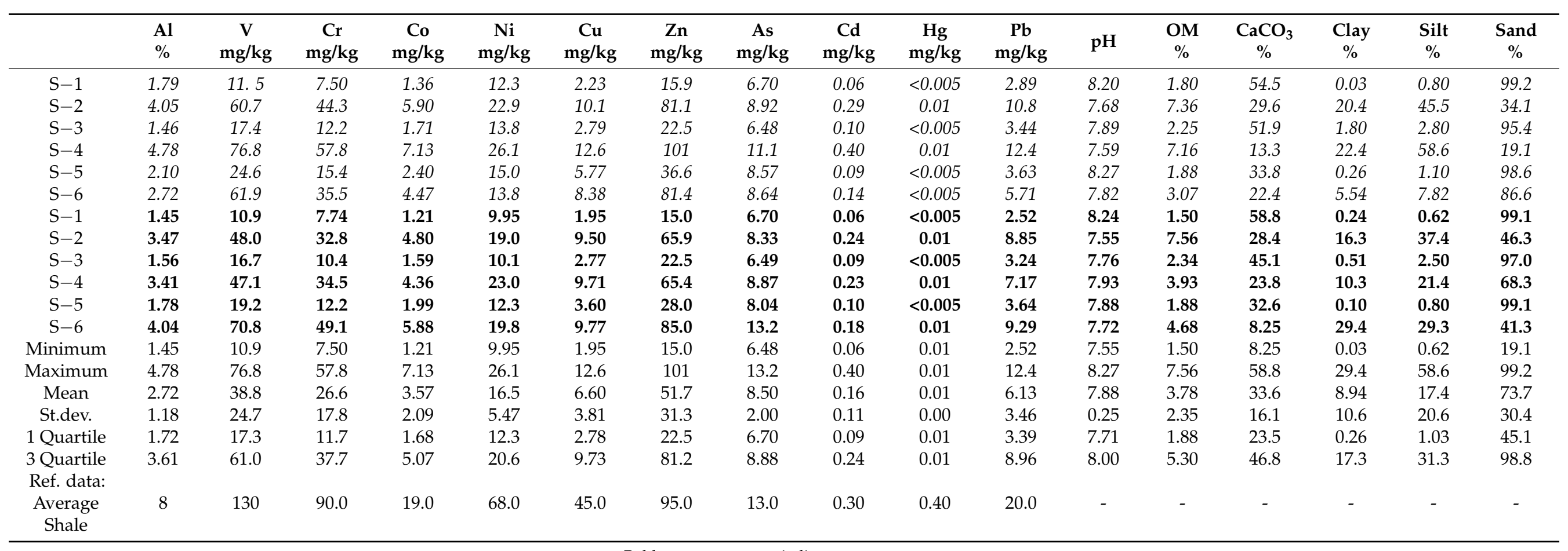



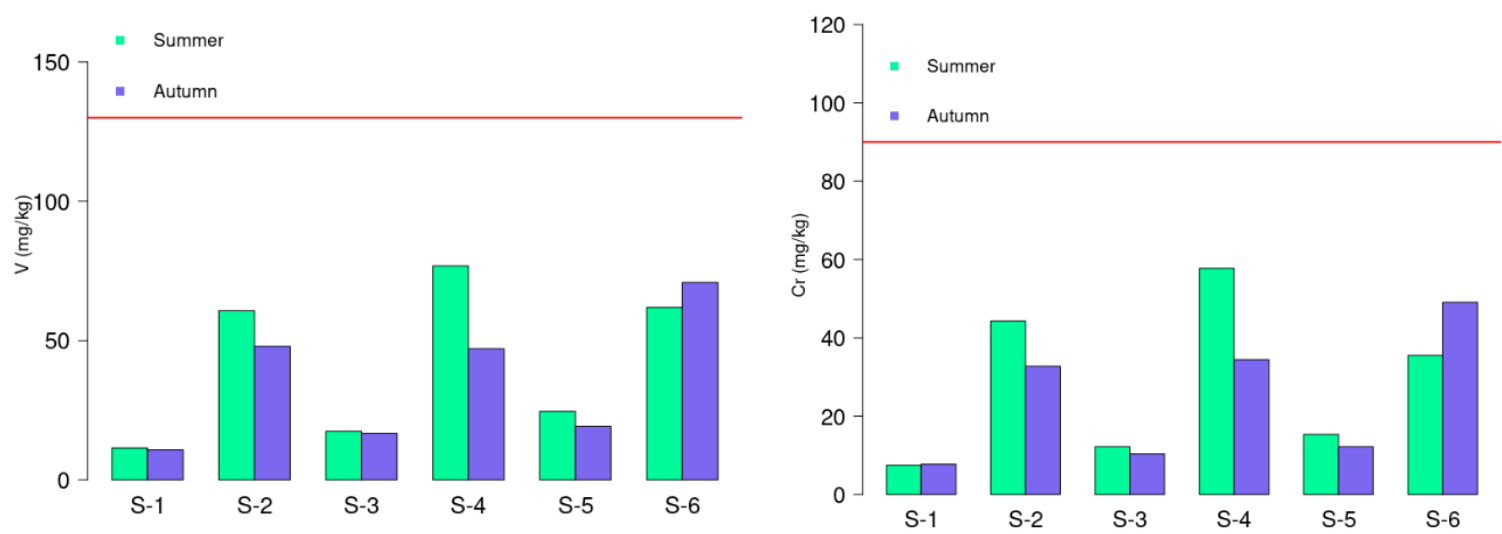

(a)

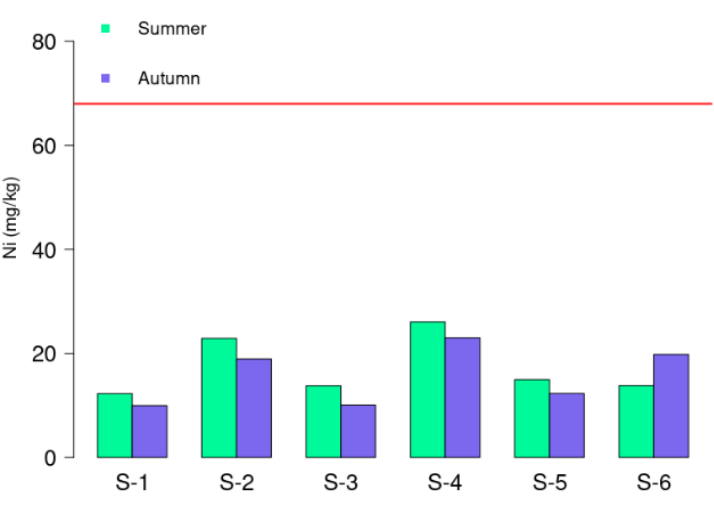

(c)

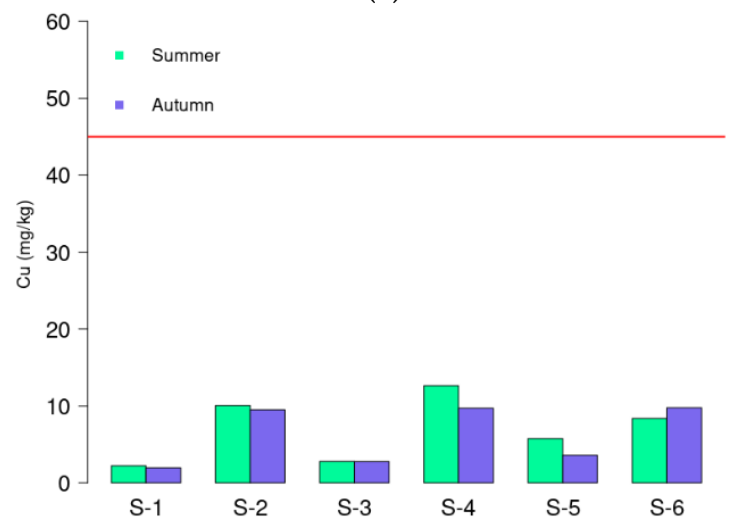

(d)

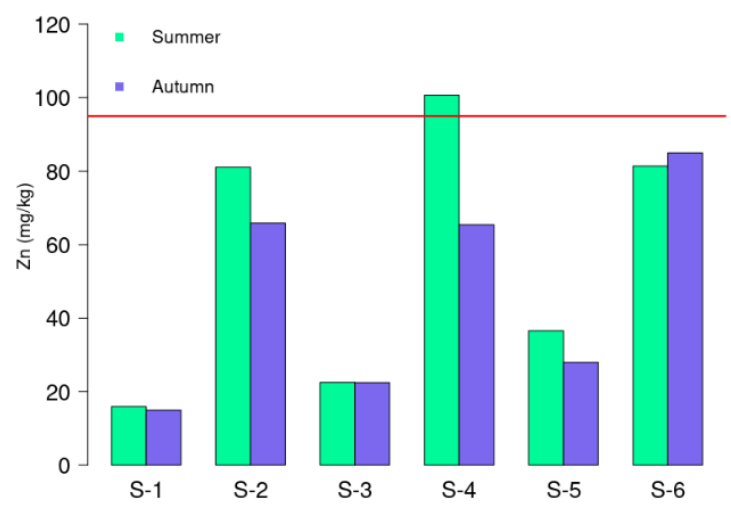

(e)

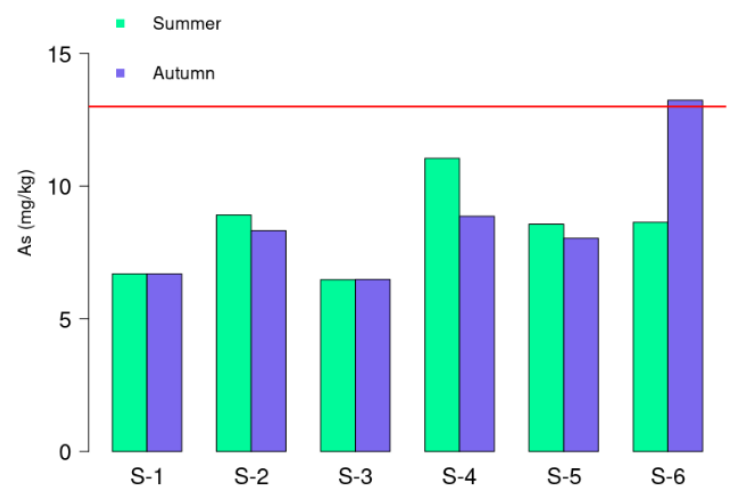

(g)

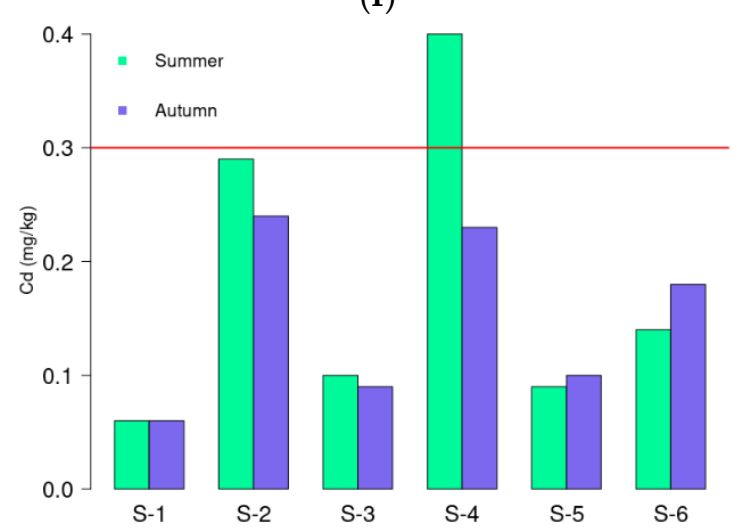

(h)

Figure 3. Cont. 


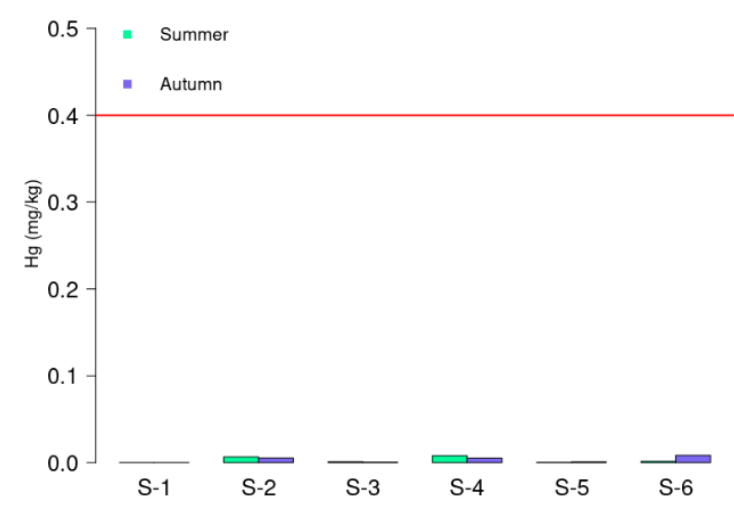

(i)

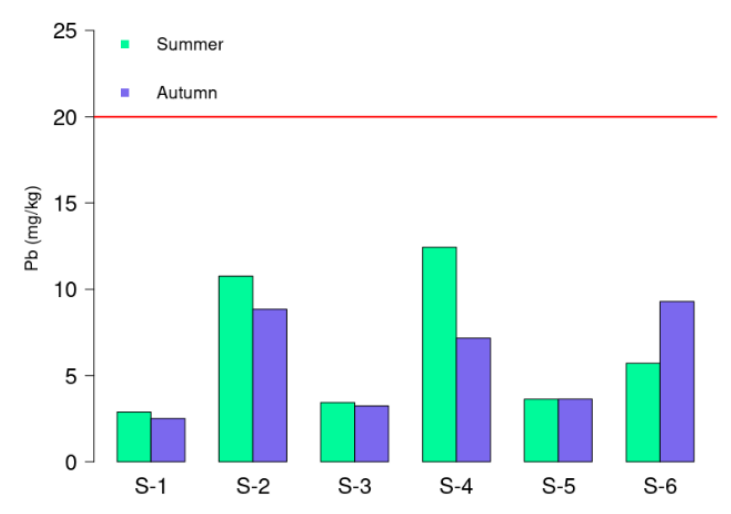

(j)

Figure 3. Spatial variations of the investigated metals during summer and autumn of the surface sediments from Khnifiss Lagoon: (a) Vanadium; (b) Chromium; (c) Cobalt; (d) Nickel; (e) Copper; (f) Zinc; (g) Arsenic; (h) Cadmium; (i) Mercury; (j) Lead. Horizontal solid red line represents the Average Shale Background value.

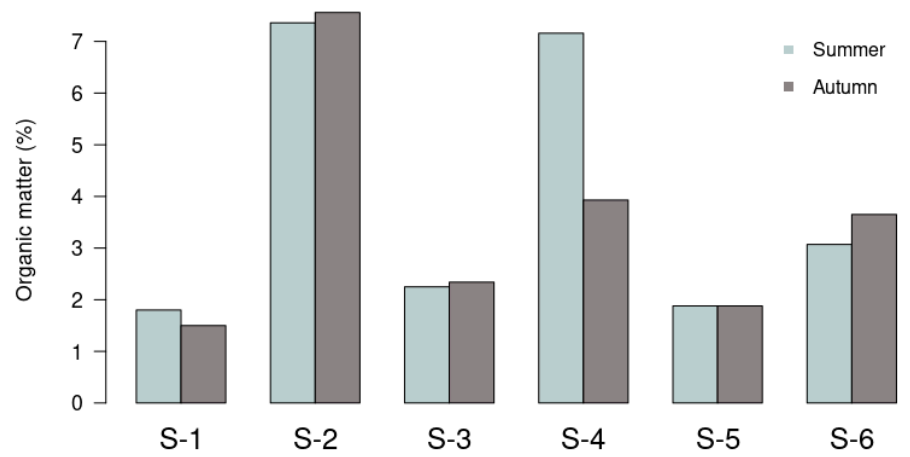

Figure 4. Organic matter (\%) distribution in Khnifiss Lagoon during summer and autumn.

Table 3. Enrichment Factor (EF) in the surface sediments from Khnifiss Lagoon.

\begin{tabular}{ccccccccccc}
\hline & $\mathbf{V}$ & $\mathbf{C r}$ & $\mathbf{C o}$ & $\mathbf{N i}$ & $\mathbf{C u}$ & $\mathbf{Z n}$ & $\mathbf{A s}$ & $\mathbf{C d}$ & $\mathbf{H g}$ & $\mathbf{P b}$ \\
\hline S-1 & 0.39 & 0.37 & 0.32 & 0.81 & 0.22 & 0.75 & 2.30 & 0.86 & 0 & 0.65 \\
$\mathrm{~S}-2$ & 0.92 & 0.97 & 0.61 & 0.67 & 0.44 & 1.69 & 1.36 & 1.94 & 0.03 & 1.06 \\
$\mathrm{~S}-3$ & 0.73 & 0.74 & 0.49 & 1.11 & 0.34 & 1.30 & 2.73 & 1.73 & 0.01 & 0.94 \\
S-4 & 0.99 & 1.07 & 0.63 & 0.64 & 0.47 & 1.78 & 1.42 & 2.22 & 0.03 & 1.04 \\
S-5 & 0.72 & 0.65 & 0.48 & 0.84 & 0.49 & 1.47 & 2.51 & 1.12 & 0 & 0.69 \\
S-6 & 1.40 & 1.16 & 0.69 & 0.60 & 0.55 & 2.52 & 1.95 & 1.41 & 0.01 & 0.84 \\
S-1 & $\mathbf{0 . 4 6}$ & $\mathbf{0 . 4 8}$ & $\mathbf{0 . 3 5}$ & $\mathbf{0 . 8 1}$ & $\mathbf{0 . 2 4}$ & $\mathbf{0 . 8 7}$ & $\mathbf{2 . 8 5}$ & $\mathbf{1 . 0 2}$ & $\mathbf{0}$ & $\mathbf{0 . 7 0}$ \\
S-2 & $\mathbf{0 . 8 5}$ & $\mathbf{0 . 8 4}$ & $\mathbf{0 . 5 8}$ & $\mathbf{0 . 6 4}$ & $\mathbf{0 . 4 9}$ & $\mathbf{1 . 6 0}$ & $\mathbf{1 . 4 8}$ & $\mathbf{1 . 8 7}$ & $\mathbf{0 . 0 3}$ & $\mathbf{1 . 0 2}$ \\
S-3 & $\mathbf{0 . 6 6}$ & $\mathbf{0 . 5 9}$ & $\mathbf{0 . 4 3}$ & $\mathbf{0 . 7 6}$ & $\mathbf{0 . 3 2}$ & $\mathbf{1 . 2 1}$ & $\mathbf{2 . 5 6}$ & $\mathbf{1 . 4 7}$ & $\mathbf{0 . 0 1}$ & $\mathbf{0 . 8 3}$ \\
S-4 & $\mathbf{0 . 8 5}$ & $\mathbf{0 . 9 0}$ & $\mathbf{0 . 5 4}$ & $\mathbf{0 . 7 9}$ & $\mathbf{0 . 5 1}$ & $\mathbf{1 . 6 1}$ & $\mathbf{1 . 6 0}$ & $\mathbf{1 . 8 4}$ & $\mathbf{0 . 0 3}$ & $\mathbf{0 . 8 4}$ \\
S-5 & $\mathbf{0 . 6 6}$ & $\mathbf{0 . 6 1}$ & $\mathbf{0 . 4 7}$ & $\mathbf{0 . 8 1}$ & $\mathbf{0 . 3 6}$ & $\mathbf{1 . 3 2}$ & $\mathbf{2 . 7 8}$ & $\mathbf{1 . 4 9}$ & $\mathbf{0 . 0 1}$ & $\mathbf{0 . 8 2}$ \\
S-6 & $\mathbf{1 . 0 8}$ & $\mathbf{1 . 0 8}$ & $\mathbf{0 . 6 1}$ & $\mathbf{0 . 5 8}$ & $\mathbf{0 . 4 3}$ & $\mathbf{1 . 7 7}$ & $\mathbf{2 . 0 2}$ & $\mathbf{1 . 1 9}$ & $\mathbf{0 . 0 4}$ & $\mathbf{0 . 9 2}$ \\
Average & 0.81 & 0.79 & 0.52 & 0.75 & 0.40 & 1.49 & 2.13 & 1.51 & 0.02 & 0.86 \\
\hline
\end{tabular}

Bold: autumn season; italic: summer season.

\subsection{Correlation Matrix}

The Spearman's correlation coefficients for Al, the OM and the studied metals (Al normalized) are presented in Table 4. According to the results, some trace metals (especially $\mathrm{V}$, $\mathrm{Cr}, \mathrm{Co}, \mathrm{Zn}$, and $\mathrm{Pb}$ ) show a very good correlation with the $\mathrm{OM}, \mathrm{Al}$, clay, and silt, indicating that their distribution in the samples is mainly controlled by the OM and the sediment's fine fraction; moreover, this evidence suggests that the geogenic source of these trace element is still predominant over anthropogenic sources. 


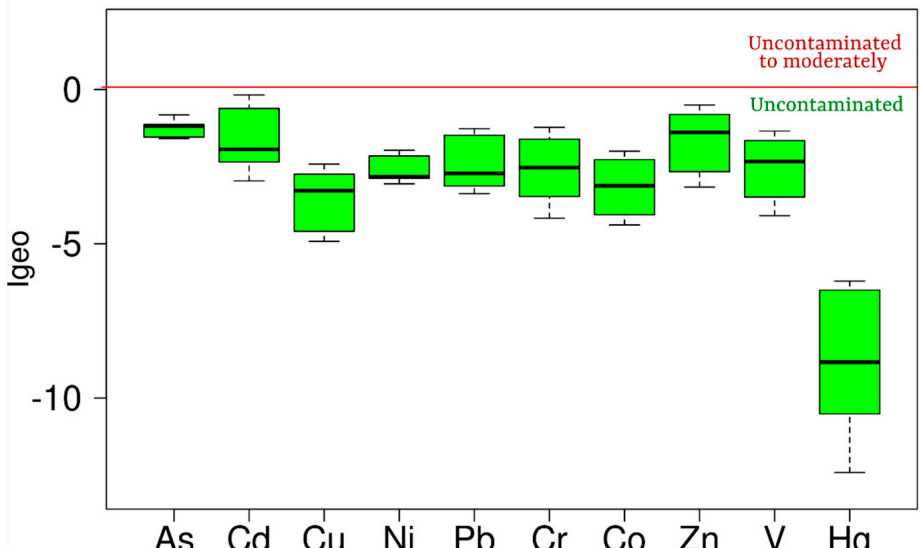

(a)

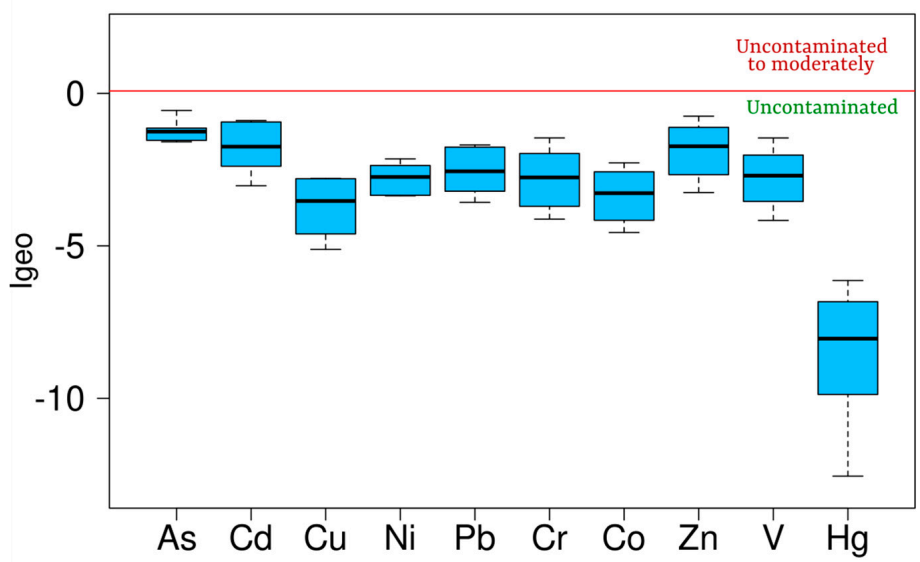

(b)

Figure 5. The Index of geo-accumulation (Igeo) of metals in Khnifiss sediments: (a) Summer season; (b) autumn season.

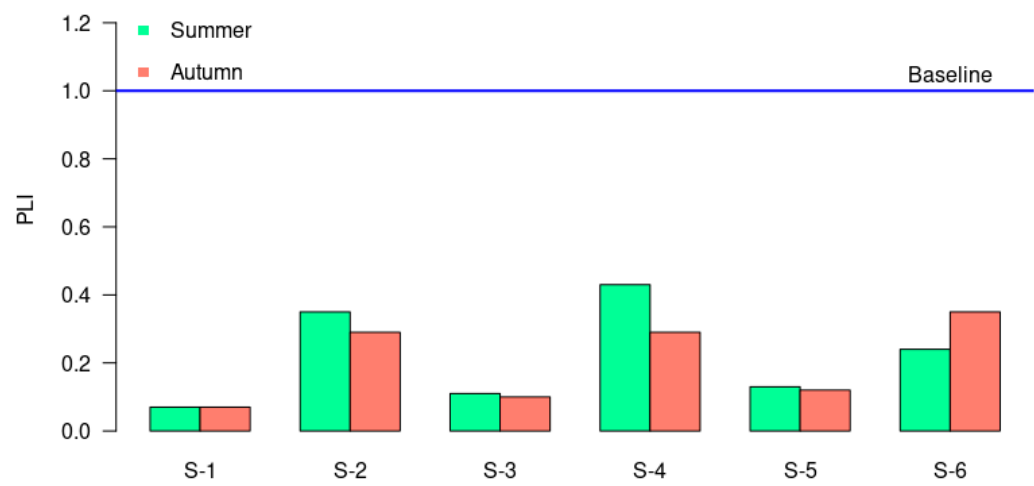

Figure 6. Pollution Load Index (PLI) for all sediments from Khnifiss Lagoon.

\subsection{Comparison with Other Studies}

The overall results were compared with the data published in a selection of papers focused on lagoon areas of Morocco and other countries around the world (Table 5) [7,58,59,64,67-75]. With the exclusion of the data from Rumisha et al. [68] at Dar es Salam coast (Tanzania), the amounts of trace metals at Khnifiss Lagoon were lower than the ones found in the other sites. Furthermore, a comparison of our results with previous studies in the Khnifiss area reveals that the levels of all trace metals, except for $\mathrm{Pb}$ and $\mathrm{Zn}$, are two times lower than those reported by Idardare et al. [64]. 
Table 4. Spearman's correlation matrix in Khnifiss Lagoon sediments.

\begin{tabular}{|c|c|c|c|c|c|c|c|c|c|c|c|c|c|c|c|c|c|}
\hline & $\mathrm{Al}$ & V & $\mathrm{Cr}$ & Co & $\mathbf{N i}$ & $\mathrm{Cu}$ & $\mathrm{Zn}$ & As & $\mathrm{Cd}$ & $\mathrm{Hg}$ & $\mathrm{Pb}$ & $\mathrm{pH}$ & OM & $\mathrm{CaCO}_{3}$ & Clay & Silt & Sand \\
\hline Al & - & 0.66 & 0.66 & 0.66 & -0.77 & 0.49 & 0.77 & -0.89 & 0.66 & -0.83 & 0.60 & -0.77 & 0.77 & -0.89 & 0.83 & 0.83 & -0.83 \\
\hline V & 1.00 & - & 1.00 & 1.00 & -0.77 & 0.66 & 0.94 & -0.54 & 0.66 & -0.62 & 0.60 & -0.77 & 0.77 & -0.89 & 0.83 & 0.83 & -0.83 \\
\hline $\mathrm{Cr}$ & 0.94 & 0.94 & - & 1.00 & -0.77 & 0.66 & 0.94 & -0.54 & 0.66 & -0.62 & 0.60 & -0.77 & 0.77 & -0.89 & 0.83 & 0.83 & -0.83 \\
\hline $\mathrm{Ni}$ & -0.71 & -0.71 & -0.60 & -0.71 & - & -0.54 & -0.83 & 0.77 & -0.31 & 0.62 & -0.26 & 0.66 & -0.54 & 0.77 & -0.60 & -0.60 & 0.60 \\
\hline $\mathrm{Cu}$ & 0.77 & 0.77 & 0.83 & 0.77 & -0.37 & - & 0.83 & -0.20 & 0.14 & -0.83 & 0.09 & -0.14 & 0.31 & -0.71 & 0.37 & 0.37 & -0.37 \\
\hline $\mathrm{Zn}$ & 0.94 & 0.94 & 1.00 & 0.94 & -0.60 & 0.83 & - & -0.60 & 0.54 & -0.83 & 0.49 & -0.66 & 0.71 & -0.94 & 0.77 & 0.77 & -0.77 \\
\hline As & -0.77 & -0.77 & -0.71 & -0.77 & 0.66 & -0.89 & -0.71 & - & -0.54 & 0.62 & -0.60 & 0.77 & -0.77 & 0.66 & -0.71 & -0.71 & 0.71 \\
\hline $\mathrm{Hg}$ & -0.88 & -0.88 & -0.88 & -0.88 & 0.68 & -0.88 & -0.88 & 0.88 & -0.41 & - & -0.41 & 0.41 & -0.62 & 0.83 & -0.62 & -0.62 & 0.62 \\
\hline $\mathrm{Pb}$ & 0.89 & 0.89 & 0.77 & 0.89 & -0.83 & 0.77 & 0.77 & -0.94 & 0.48 & -0.88 & - & -0.83 & 0.94 & -0.60 & 0.89 & 0.89 & -0.89 \\
\hline $\mathrm{pH}$ & -0.71 & -0.71 & -0.49 & -0.71 & 0.77 & -0.37 & -0.49 & 0.66 & -0.24 & 0.49 & -0.83 & - & -0.89 & 0.77 & -0.94 & -0.94 & 0.94 \\
\hline OM & 0.89 & 0.89 & 0.77 & 0.89 & -0.83 & 0.77 & 0.77 & -0.94 & 0.48 & -0.88 & 1.00 & -0.83 & - & -0.77 & 0.94 & 0.94 & -0.94 \\
\hline $\mathrm{CaCO}_{3}$ & -0.94 & -0.94 & -1.00 & -0.94 & 0.60 & -0.83 & -1.00 & 0.71 & -0.24 & 0.88 & -0.77 & 0.49 & -0.77 & - & -0.89 & -0.89 & 0.89 \\
\hline Clay & 0.83 & 0.83 & 0.77 & 0.83 & -0.94 & 0.60 & 0.77 & -0.77 & 0.12 & -0.88 & 0.89 & -0.66 & 0.89 & -0.77 & - & 1.00 & -1.00 \\
\hline Silt & 0.89 & 0.89 & 0.77 & 0.89 & -0.83 & 0.77 & 0.77 & -0.94 & 0.48 & -0.88 & 1.00 & -0.83 & 1.00 & -0.77 & 0.89 & - & -1.00 \\
\hline Sand & -0.94 & -0.94 & -0.89 & -0.94 & 0.89 & -0.71 & -0.89 & 0.83 & -0.24 & 0.88 & -0.94 & 0.77 & -0.94 & 0.89 & -0.94 & -0.94 & - \\
\hline
\end{tabular}

Bold: autumn season; italic: summer season.

Table 5. Metal concentrations ( $\mathrm{mg} / \mathrm{kg}$ ), as dry weight, measured for the present study (ranges and mean) and comparison with other lagoon areas around the world.

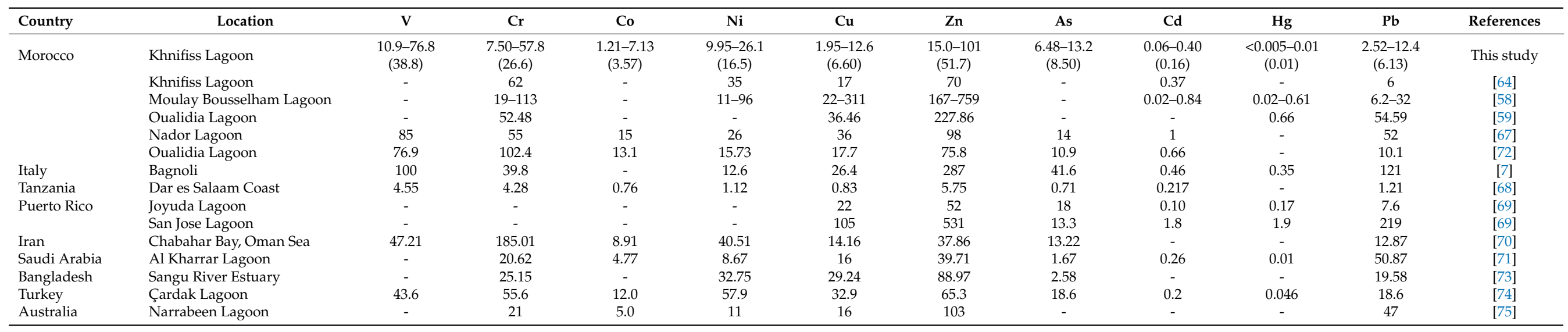




\section{Conclusions}

In this study, 10 trace metals $(\mathrm{V}, \mathrm{Cr}, \mathrm{Co}, \mathrm{Ni}, \mathrm{Cu}, \mathrm{Zn}, \mathrm{As}, \mathrm{Cd}, \mathrm{Hg}$, and $\mathrm{Pb}$ ) in surface sediments from Khnifiss Lagoon (Morocco) were examined and compared to the values found in the lagoon sediments from other countries and with the literature background data. The results, including correlations and a selection of contamination indices, suggested that the trace element contents in Khnifiss Lagoon are of natural origin and not significantly affected by anthropogenic sources. The current status of the area is also related to the limited access to the ecosystem, denoting a good example of wetland management. Our data represent only a preliminary screening that can be used as a starting point for a more detailed evaluation of the background levels of trace metals in the Moroccan lagoon areas. Further investigations are in progress on the site, including the study of the trace metals temporal trend. Due to the presence of low concentrations of trace metals, periodic monitoring campaigns of the lagoon are required, in order to highlight any possible earlystage contamination event and to limit/reduce any negative effects utilizing the best environmental management practices available.

Author Contributions: Conceptualization, A.T.; investigation, A.T., R.C., C.C., M.D.C., E.N. and M.R.M.; validation, E.N. and M.R.M.; formal analysis, A.T. and L.P.; data curation, A.T. and L.P.; writingoriginal draft preparation, A.T. and F.S.; writing-review and editing, F.S. and M.P.; supervision, M.A., G.A. and B.Z. All authors have read and agreed to the published version of the manuscript.

Funding: This research received no external funding.

Acknowledgments: The first author (A.T.) is deeply thankful to the ENEA laboratory (Italy) for providing all necessary research facilities, and greatly acknowledges the receipt of a fellowship from the ICTP Programme for Training and Research in Italian Laboratories, Trieste, Italy. The authors thank also the "Haut Commissariat aux Eaux Et Forêts et à la Lutte Contre la Désertification" for giving access during the sampling campaign. They are also delighted to express their gratitude and sincere thanks to the editor and the reviewers for their useful comments and suggestions to improve the quality of this article.

Conflicts of Interest: The authors declare no conflict of interest.

\section{References}

1. Mitsch, W.J.; Gosselink, J.G. Wetlands, 5th ed.; John Wiley \& Sons, Inc.: Hoboken, NJ, USA, 2015.

2. Van Den Broeck, M.; Waterkeyn, A.; Rhazi, L.; Grillas, P.; Brendonck, L. Assessing the ecological integrity of endorheic wetlands, with focus on Mediterranean temporary ponds. Ecol. Indic. 2015, 54, 1-11. [CrossRef]

3. Zourarah, B.; Maanan, M.; Robin, M.; Carruesco, C. Sedimentary records of anthropogenic contribution to heavy metal content in Oum Er Bia estuary (Morocco). Environ. Chem. Lett. 2009, 7, 67-78. [CrossRef]

4. Pérez-Ruzafa, A.; Marcos, C.; Pérez-Ruzafa, I.M.; Pérez-Marcos, M. Coastal lagoons: "Transitional ecosystems" between transitional and coastal waters. J. Coast. Conserv. 2011, 15, 369-392. [CrossRef]

5. Stanley, M.C.; Beggs, J.R.; Bassett, I.E.; Burns, B.R.; Dirks, K.N.; Jones, D.N.; Linklater, W.L.; Macinnis-Ng, C.; Simcock, R.; Souter-Brown, G.; et al. Emerging threats in urban ecosystems: A horizon scanning exercise. Front. Ecol. Environ. 2015, 13, 553-560. [CrossRef]

6. Patel, P.; Raju, N.J.; Reddy, B.C.S.R.; Suresh, U.; Sankar, D.B.; Reddy, T.V.K. Heavy metal contamination in river water and sediments of the Swarnamukhi River Basin, India: Risk assessment and environmental implications. Environ. Geochem. Health 2018, 40, 609-623. [CrossRef]

7. Armiento, G.; Caprioli, R.; Cerbone, A.; Chiavarini, S.; Crovato, C.; De Cassan, M.; De Rosa, L.; Montereali, M.R.; Nardi, E.; Nardi, L.; et al. Current status of coastal sediments contamination in the former industrial area of Bagnoli-Coroglio (Naples, Italy). Chem. Ecol. 2020. [CrossRef]

8. Tabelin, C.B.; Igarashi, T.; Villacorte-Tabelin, M.; Park, P.; Opiso, E.M.; Ito, M.; Hiroyoshi, N. Arsenic, selenium, boron, lead, cadmium, copper, and zinc in naturally contaminated rocks: A review of their sources, modes of enrichment, mechanisms of release, and mitigation strategies. Sci. Total Environ. 2018, 645, 1522-1553. [CrossRef]

9. Liu, J.; Song, J.; Yuan, H.; Li, X.; Li, N.; Duan, L. Trace metal comparative analysis of sinking particles and sediments from a coastal environment of the Jiaozhou Bay, North China: Influence from sediment resuspension. Chemosphere 2019, 232, 315-326. [CrossRef]

10. Huyen, D.T.; Tabelin, C.B.; Thuan, H.M.; Dang, H.D.; Truong, P.T.; Vongphuthone, B.; Kobayashi, M.; Igarashi, T. The solid-phase partitioning of arsenic in unconsolidated sediments of the Mekong Delta, Vietnam and its modes of release under various conditions. Chemosphere 2019, 233, 512-523. [CrossRef] 
11. Guédron, S.; Tisserand, D.; Garambois, S.; Spadini, L.; Molton, F.; Bounvilay, B.; Charlet, L.; Polya, D.A. Baseline investigation of (methyl)mercury in waters, soils, sediments and key foodstuffs in the Lower Mekong Basin: The rapidly developing city of Vientiane (Lao PDR). J. Geochem. Explor. 2014, 143, 96-102. [CrossRef]

12. Karthikeyan, P.; Marigoudar, S.R.; Mohan, D.; Nagarjuna, A.; Sharma, K.V. Ecological risk from heavy metals in Ennore estuary, South East coast of India. Environ. Chem. Ecotoxicol. 2020, 2, 182-193. [CrossRef]

13. Morillo, J.; Usero, J.; Gracia, I. Potential mobility of metals in polluted coastal sediments in two bays of southern Spain. J. Coast. Res. 2007, 23, 352-361. [CrossRef]

14. Zaidi, A.; Wani, P.A.; Khan, M.S. Toxicity of heavy metals to legumes and bioremediation. In Toxicity of Heavy Metals to Legumes and Bioremediation; Springer: Vienna, Austria, 2014; pp. 29-44. [CrossRef]

15. Dong, W.Q.Y.; Cui, Y.; Liu, X. Instances of soil and crop heavy metal contamination in China. Soil Sediment Contam. 2001, 10, 497-510. [CrossRef]

16. Facchinelli, A.; Sacchi, E.; Mallen, L. Multivariate statistical and GIS-based approach to identify heavy metal sources in soils. Environ. Pollut. 2001, 114, 313-324. [CrossRef]

17. Solgi, E.; Abbas, E.S.; Alireza, R.B.; Hadipour, M. Soil contamination of metals in the three industrial estates, Arak, Iran. Bull. Environ. Contam. Toxicol. 2012, 88, 634-638. [CrossRef] [PubMed]

18. Zheng, L.; Wu, K.; Li, Y.; Qi, Z.; Han, D.; Zhang, B.; Gu, C.; Chen, G.; Liu, J.; Chen, S.; et al. Blood lead and cadmium levels and relevant factors among children from an e-waste recycling town in China. Environ. Res. 2008, 108, 15-20. [CrossRef] [PubMed]

19. Amin, B.; Ismail, A.; Arshad, A.; Yap, C.K.; Kamarudin, M.S. Anthropogenic impacts on heavy metal concentrations in the coastal sediments of Dumai, Indonesia. Environ. Monit. Assess. 2009, 148, 291-305. [CrossRef]

20. Wen, L.S.; Santschi, P.; Gill, G.; Paternostro, C. Estuarine trace metal distributions in Galveston Bay: Importance of colloidal forms in the speciation of the dissolved phase. Mar. Chem. 1999, 63, 185-212. [CrossRef]

21. Mounier, S.; Lacerda, L.D.; Marins, R.V.; Bemaim, J. Copper and Mercury Complexing Capacity of Organic Matter from a Mangrove Mud Flat Environment, Sepetiba Bay, Brazil. Bull. Environ. Contam. Toxicol. 2001, 67, 0519-0525. [CrossRef]

22. Orbi, A.; Nemmaoui, M. Fluctuation des vents et variabilité de l'upwelling le long de la Côte Atlantique Marocaine. Trav. Doc. Inst. Natl. Rech. Halieut. 1992, 75, 27.

23. Lefrere, L.; Ouassas, M.; Guillois, B.; Gillet, P.; Moukrim, A. Macrobenthic community structure of soft-bottom sediments in the Khnifiss lagoon, South of Morocco. J. Mater. Environ. Sci. 2015, 6, 3226-3235.

24. RGPH. Recensement Général de la Population et de l'Habitat; Royaume du Maroc: Rabat, Morocco, 2014; Available online: http: / /rgphentableaux.hcp.ma/ (accessed on 10 June 2020).

25. Beaubrun, P.C. La lagune de Khnifiss: Premières observations sur les sédiments et l'hydrologie du milieu. Bull. Inst. Sci 1976, 1, 50-65.

26. Lakhdar Idrissi, J.; Orbi, A.; Zidane, F.; Hilmi, K.; Sarf, F.; Massik, Z.; Makaoui, A. Organisation et fonctionnement d'un écosystème côtier du Maroc: La lagune de Khnifiss. Rev. Sci. L'eau 2004, 17, 447-462. [CrossRef]

27. El Agbani, M.A.; Fekhaoui, M.; Bayed, A.; Schouten, J. The Khnifiss lagoon and adjacent waters: Hydrology and hydrodynamics. In The Khnifiss Lagoon and Its Surrounding Environment (Province of La'youne, Morocco); Dakki, M., de Ligny, W., Eds.; Travaux de l'Institut Scientifique: Rabat, Morocco, 1988; pp. 17-26.

28. Hassi, M.; Alouani, M.; Faaras, M.S.; Staiti, M. Qualitative and quantitative study of the spring phytoplankton community in the Naila lagoon (Moroccan Atlantic coast). J. Mater. Environ. Sci. 2020, 11, 977-987.

29. Edmondson, J.; Gunn, A.; Burt, A.J.; Parker, D.M. Checklist of Flora of the Khnifiss-Tarfaya region (Morocco). In The Khnifiss Lagoon and Its Surrounding Environment (Province of La'youne, Morocco); Dakki, M., de Ligny, W., Eds.; Travaux de l'Institut Scientifique: Rabat, Morocco, 1988; pp. 41-45.

30. Russel, G.; Hockin, D.C. The Seaweeds of the Khnifiss lagoon and the Tarfaya coast. In The Khnifiss Lagoon and Its Surrounding Environment (Province of La'youne, Morocco); Dakki, M., de Ligny, W., Eds.; Travaux de l'Institut Scientifique: Rabat, Morocco, 1988; pp. 37-40.

31. Dillon, W.P.; Sougy, J.M.A. Geology of West Africa and Canary and Cape Verde Islands; Springer Science and Business Media LLC: Boston, MA, USA, 1974; pp. 315-390.

32. Choubert, G.; Faure-Muret, A.; Hottinger, L.; Viotti, G.; Lecointre, G. Le bassin côtier de Tarfaya (Maroc méridional). Notes Mém. Serv. Géol. Maroc. 1966, 175, 1-285.

33. Michard, A.; Saddiqi, O.; Chalouan, A.; de Lamotte, D.F. (Eds.) Continental Evolution: The Geology of Morocco; Lecture Notes in Earth Sciences; Springer: Berlin/Heidelberg, Germany, 2008; Volume 116, ISBN 978-3-540-77075-6.

34. Ranke, U.; von Rad, U.; Wissmann, G. Stratigraphy, facies and tectonic development of the on-and offshore Aaiun-Tarfaya Basin-A review. In Geology of the Northwest African Continental Margin; Springer: Berlin/Heidelberg, Germany, $1982 ;$ pp. 86-105.

35. Gilli, R.; Karlen, C.; Weber, M.; Rüegg, J.; Barmettler, K.; Biester, H.; Boivin, P.; Kretzschmar, R. Speciation and Mobility of Mercury in Soils Contaminated by Legacy Emissions from a Chemical Factory in the Rhône Valley in Canton of Valais, Switzerland. Soil Syst. 2018, 2, 44. [CrossRef]

36. Franzen, C.; Kilian, R.; Biester, H. Natural mercury enrichment in a minerogenic fen-Evaluation of sources and processes. J. Environ. Monit. 2004, 6, 466-472. [CrossRef]

37. Heiri, O.; Lotter, A.F.; Lemcke, G. Loss on ignition as a method for estimating organic and carbonate content in sediments: Reproducibility and comparability of results. J. Paleolimnol. 2001, 25, 101-110. [CrossRef] 
38. Lamas, F.; Irigaray, C.; Oteo, C.; Chacón, J. Selection of the most appropriate method to determine the carbonate content for engineering purposes with particular regard to marls. Eng. Geol. 2005, 81, 32-41. [CrossRef]

39. Valdés, J.; Vargas, G.; Sifeddine, A.; Ortlieb, L.; Guiñez, M. Distribution and enrichment evaluation of heavy metals in Mejillones Bay $\left(23^{\circ}\right.$ S), Northern Chile: Geochemical and statistical approach. Mar. Pollut. Bull. 2005, 50, 1558-1568. [CrossRef]

40. Rowell, D. Soil Science: Methods \& Applications; Longman Scientific \& Technical: London, UK, 1994.

41. Muller, G. Methods in sedimentary petrology. In Sedimentary Petrology (Pt. I); Engelhardt, W.V., Fiichtbauer, H., Muller, G., Eds.; Schweitzerbartsche Verlagsbuchhandlung: Stuttgart, Germany, 1967.

42. Bao, K.; Jia, L.; Lu, X.; Wang, G. Grain-size characteristics of sediment in Daniugou Peatland in Changbai Mountains, Northeast China: Implications for atmospheric dust deposition. Chin. Geogr. Sci. 2010, 20, 498-505. [CrossRef]

43. Tabelin, C.B.; Silwamba, M.; Paglinawan, F.C.; Mondejar, A.J.S.; Duc, H.G.; Resabal, V.J.; Opiso, E.M.; Igarashi, T.; Tomiyama, S.; Ito, M.; et al. Solid-phase partitioning and release-retention mechanisms of copper, lead, zinc and arsenic in soils impacted by artisanal and small-scale gold mining (ASGM) activities. Chemosphere 2020, 260, 127574. [CrossRef] [PubMed]

44. Bantan, R.A.; Al-Dubai, T.A.; Al-Zubieri, A.G. Geo-environmental assessment of heavy metals in the bottom sediments of the Southern Corniche of Jeddah, Saudi Arabia. Mar. Pollut. Bull. 2020, 161, 111721. [CrossRef] [PubMed]

45. Turekian, K.K.; Wedepohl, K.H. Distribution of the Elements in Some Major Units of the Earth's Crust. Geol. Soc. Am. Bull. 1961, 72, 175-192. [CrossRef]

46. Loska, K.; Cebula, J.; Pelczar, J.; Wiechuła, D.; Kwapuliński, J. Use of enrichment, and contamination factors together with geoaccumulation indexes to evaluate the content of $\mathrm{Cd}, \mathrm{Cu}$, and $\mathrm{Ni}$ in the Rybnik water Reservoir in Poland. Water Air Soil Pollut. 1997, 93, 347-365. [CrossRef]

47. Mata, H.K.; Al Salah, D.M.M.; Ngweme, G.N.; Konde, J.N.; Mulaji, C.K.; Kiyombo, G.M.; Poté, J.W. Toxic metal concentration and ecotoxicity test of sediments from dense populated areas of Congo River, Kinshasa, Democratic Republic of the Congo. Environ. Chem. Ecotoxicol. 2020, 2, 83-90. [CrossRef]

48. Liaghati, T.; Preda, M.; Cox, M. Heavy metal distribution and controlling factors within coastal plain sediments, Bells Creek catchment, southeast Queensland, Australia. Environ. Int. 2004, 29, 935-948. [CrossRef]

49. Guan, Q.; Wang, L.; Pan, B.; Guan, W.; Sun, X.; Cai, A. Chemosphere Distribution features and controls of heavy metals in surface sediments from the riverbed of the Ningxia-Inner Mongolian reaches, Yellow River, China. Chemosphere 2016, 144, 29-42. [CrossRef]

50. Muller, G. Index of geoaccumulation in sediments of the Rhine River. Geol. J. 1969, 2, 109-118.

51. Zhang, W.; Feng, H.; Chang, J.; Qu, J.; Xie, H.; Yu, L. Heavy metal contamination in surface sediments of Yangtze River intertidal zone: An assessment from different indexes. Environ. Pollut. 2009, 157, 1533-1543. [CrossRef]

52. Chakraborty, P.; Ramteke, D.; Chakraborty, S.; Nagender Nath, B. Changes in metal contamination levels in estuarine sediments around India-An assessment. Mar. Pollut. Bull. 2014, 78, 15-25. [CrossRef] [PubMed]

53. Tomlinson, D.L.; Wilson, J.G.; Harris, C.R.; Jeffrey, D.W. Problems in the assessment of heavy-metal levels in estuaries and the formation of a pollution index. Helgol. Meeresunters. 1980, 33, 566-575. [CrossRef]

54. Buccolieri, A.; Buccolieri, G.; Cardellicchio, N.; Dell'Atti, A.; Di Leo, A.; Maci, A. Heavy metals in marine sediments of Taranto Gulf (Ionian Sea, Southern Italy). Mar. Chem. 2006, 99, 227-235. [CrossRef]

55. Gong, Q.; Deng, J.; Xiang, Y.; Wang, Q.; Yang, L. Calculating Pollution Indices by Heavy Metals in Ecological Geochemistry Assessment and a Case Study in Parks of Beijing. J. China Univ. Geosci. 2008, 19, 230-241. [CrossRef]

56. R Core Team. A Language and Environment for Statistical Computing; R Foundation for Statistical Computing: Vienna, Austria, 2020; Available online: http:/ / www.r-project.org/ (accessed on 13 May 2020).

57. Leenheer, J.A. Analysis, association, and effects of organic constituents of aquatic constituents sediments. In The Role of Sediments in the Chemistry of Aquatic Systems; Bradford, L., Horowitz, J.A., Eds.; U.S. Geo-logical Survey Circular 969; U.S. Government Printing Office: Washington, DC, USA, 1982; pp. 22-32.

58. Alaoui, A.M.; Choura, M.; Maanan, M.; Zourarah, B.; Robin, M.; Conceição, M.F.; Andrade, C.; Khalid, M.; Carruesco, C. Metal fluxes to the sediments of the Moulay Bousselham lagoon, Morocco. Environ. Earth Sci. 2010, 61, 275-286. [CrossRef]

59. Zourarah, B.; Maanan, M.; Carruesco, C.; Aajjane, A.; Mehdi, K.; Conceição Freitas, M. Fifty-year sedimentary record of heavy metal pollution in the lagoon of Oualidia (Moroccan Atlantic coast). Estuar. Coast. Shelf Sci. 2007, 72, 359-369. [CrossRef]

60. Villalobos, M.; Leckie, J. The role of carbonate in trace metal soil pollution. Rev. Int. Contam. Ambient 2000, 16, 157-167.

61. Drever, J.I. The Geochemistry of Natural Waters, 2nd ed.; Prentice-Hall: New York, NY, USA, 2008.

62. Callender, E. Heavy metals in the environment-Historical trends. In Treatise on Geochemistry, 2nd ed.; Holland, H.D., Turekian, K.K., Eds.; Elsevier: Amsterdam, The Netherlands, 2014; pp. 59-89.

63. Birch, G.F. Determination of sediment metal background concentrations and enrichment in marine environments-A critical review. Sci. Total Environ. 2017, 580, 813-831. [CrossRef]

64. Idardare, Z.; Chiffoleau, J.-F.; Moukrim, A.; Alla, A.A.; Auger, D.; Lefrere, L.; Rozuel, E. Metal concentrations in sediment andNereis diversicolorin two Moroccan lagoons: Khnifiss and Oualidia. Chem. Ecol. 2008, 24, 329-340. [CrossRef]

65. Leine, L. Geology of the Tarfaya oil shale deposit, Morocco. Geol. Mijnb. 1986, 65, 57-74.

66. Atgin, S.R.; El-Agha, O.; Zararsiz, A.; Kocataş, A.; Parlak, H.; Tuncel, G. Investigation of the sediment pollution in Izmir Bay: Trace elements. Spectrochim. Acta Part B At. Spectrosc. 2000, 55, 1151-1164. [CrossRef] 
67. Bloundi, M.K.; Duplay, J.; Quaranta, G. Heavy metal contamination of coastal lagoon sediments by anthropogenic activities: The case of Nador (East Morocco). Environ. Geol. 2009, 56, 833-843. [CrossRef]

68. Rumisha, C.; Elskens, M.; Leermakers, M.; Kochzius, M. Trace metal pollution and its influence on the community structure of soft bottom molluscs in intertidal areas of the Dar es Salaam coast, Tanzania. Mar. Pollut. Bull. 2012, 64, 521-531. [CrossRef]

69. Acevedo-Figueroa, D.; Jiménez, B.D.; Rodríguez-Sierra, C.J. Trace metals in sediments of two estuarine lagoons from Puerto Rico. Environ. Pollut. 2006, 141, 336-342. [CrossRef]

70. Agah, H.; Saleh, A.; Bastami, K.D.; Fumani, N.S. Ecological risk, source and preliminary assessment of metals in the surface sediments of Chabahar Bay, Oman Sea. Mar. Pollut. Bull. 2016, 107, 383-388. [CrossRef] [PubMed]

71. Youssef, M.; El-Sorogy, A. Environmental assessment of heavy metal contamination in bottom sediments of Al-Kharrar lagoon, Rabigh, Red Sea, Saudi Arabia. Arab. J. Geosci. 2016, 9, 474. [CrossRef]

72. Mejjad, N.; Laissaoui, A.; El-Hammoumi, O.; Fekri, A.; Amsil, H.; El-Yahyaoui, A.; Benkdad, A. Geochemical, radiometric, and environmental approaches for the assessment of the intensity and chronology of metal contamination in the sediment cores from Oualidia lagoon (Morocco). Environ. Sci. Pollut. Res. 2018, 25, 22872-22888. [CrossRef]

73. Hossain, M.B.; Shanta, T.B.; Ahmed, A.S.S.; Hossain, M.K.; Semme, S.A. Baseline study of heavy metal contamination in the Sangu River estuary, Chattogram, Bangladesh. Mar. Pollut. Bull. 2019, 140, 255-261. [CrossRef]

74. Kükrer, S.; Erginal, A.E.; Kılıç, Ş.; Bay, Ö.; Akarsu, T.; Öztura, E. Ecological risk assessment of surface sediments of Çardak Lagoon along a human disturbance gradient. Environ. Monit. Assess. 2020, 192. [CrossRef]

75. Birch, G.; Lee, J.H. The use of sedimentary metal data in predictive modelling of estuarine contamination, assessment of environmental condition and pollutant source identification (Narrabeen Lagoon, Sydney, Australia). Environ. Sci. Pollut. Res. 2020. [CrossRef] 